Review

\title{
Recombinants proteins for industrial uses: utilization of Pichia pastoris expression system
}

\author{
Claudia Rabert ${ }^{1,3}$, Daniel Weinacker ${ }^{1,2}$, Adalberto Pessoa $\mathrm{Jr}^{2}$, Jorge G. Farías ${ }^{1}$ \\ ${ }^{1}$ Departamento de Ingeniería Química, Facultad de Ingeniería, Ciencias y Administración, \\ Universidad de La Frontera, Temuco, Chile. \\ ${ }^{2}$ Departamento de Tecnologia Bioquímico-Farmacêutica, Faculdade de Ciências Farmacêuticas, \\ Universidade de São Paulo, São Paulo, Brazil. \\ ${ }^{3}$ Departamento de Producción Agropecuaria, Facultad de Ciencias Agropecuarias y Forestales, \\ Universidad de La Frontera, Temuco, Chile.
}

Submitted: December 18, 2012; Approved: January 08, 2013.

\begin{abstract}
The innovation in industrial process with impact in the efficient production is the major challenge for actual industry. A high numerous of enzymes are utilized in at different level of process; the search for new alternatives with better characteristic has become a field of study of great interest, the recombinant protein achievement in a different host system is an alternative widely assessed for production of this. The microorganism Pichia pastoris has been used like a successful expression system in diverse areas, improved the yield and extraction-recovery of the product expressed. The reported of diverse authors in the production of enzymes with different application in industry is varied, in this review the different industry areas and the characteristic of the enzymes produced are detailed.
\end{abstract}

Key words: recombinant protein, protein production, yeast, industrial applications.

\section{Recombinant Protein for Industrial Use}

The production of protein for industrial use started in the end of century XIX, the industry searched new component for improve the efficiency of the process or searching alternatives to make it a most cost effective process; the development of recombinant DNA technology and the progress made in the optimization of the bioprocess with recombinant organisms offers a wide variety of alternatives in the production of proteins for use in industrial processes with new and/or better properties.

The expression systems based of recombinant proteins in yeast have proven to be an efficient and economical source of proteins of industrial interest higher eukaryotes and / or academic (Buckholz and Gleeson, 1991) becoming one of the most frequently used alternative for the production of proteins a high scale.

\section{Pichia pastoris Like an Expression System}

The use of the methylotrophic yeast, Pichia pastoris, as a cellular host for the expression of recombinant proteins has become increasing popular in recent times. $P$. pastoris is easier to genetically manipulate and culture than mammalian cells and can be grown to high cell densities. Equally important, $P$. pastoris is also a eukaryote microorganism, and thereby provides the potential for producing soluble, correctly folded recombinant proteins that have undergone all the post-translational modifications required for functionality. Additionally, linearized foreign DNA can be inserted in high efficiency via homologous recombination procedures to generate stable cell lines whilst expression vectors can be readily prepared that allow multiple copies of the target protein, multimeric proteins with different subunit structures, or alternatively the target protein and its cognate binding partners, to be expressed (Daly et al., 2004).

Recombinant protein production in the yeast strain Pichia pastoris has several advantages over other eukaryotic and prokaryotic expression systems: (i) rapid growth rate, coupled with ease of high cell-density fermentation; (ii) high levels of productivity in an almost protein-free medium; (iii) elimination of endotoxin and bacteriophage con-

Send correspondence to J.G. Farías. Departamento de Ingeniería Química, Facultad de Ingeniería, Ciencias y Administración, Universidad de La Frontera, Temuco, Chile. E-mail: jorge.farias@ufrontera.cl. 
tamination; (iv) ease of genetic manipulation of well-characterized yeast expression vectors; (v) absence of known human pathogenicity in the spectrum of lytic viruses that prey on $P$. pastoris; (vi) diverse post-translational modifications that include polypeptide folding, glycosylation, methylation, acylation, proteolytic adjustment, and targeting to subcellular compartments; and (vii) the ability to engineer secreted proteins that can be purified from growth medium without harvesting the yeast cells themselves (Li et al., 2007).

Pichia pastoris has been exploited by biotechnologists for the high-level production of foreign proteins (Cregg et al., 2004; Romanos et al., 1992). In this review will focus in the different recombinant proteins with application in diverse industrial areas expressed in the system $P$. pastoris, highlighting the applicability and the main improvements obtained through this expression system.

\section{Animal Feed Additive}

Monogastric animals are unable to utilize phytic acids due to the low levels of phytase activity in their digestive tracts, by that an inorganic phosphate source is commonly added into the feed for the purposes of phosphorous supplementation (Torre et al., 1991). The enzyme phytase catalyze the hydrolysis of phytic acid (myoinositol hexakisphosphate), the major storage form of phosphorous in plant seeds (Cheryan, 1980) thereby releasing inorganic phosphate, is regarded as an antinutrient factor since it forms insoluble complexes with proteins and a variety of nutritionally important metal ions such as calcium, zinc, magnesium, and iron, and decreasing the bioavailability of phourous (Torre et al., 1991). Microbial phytases available in the market have problem in thermoestability and degradation suffers in stomach digestion; becoming not feasible for addition in feed rations like additive. An alternative arises from $P$. pastoris for obtaining protein from prokaryotes or eukaryotes microorganisms and with high yield of enzyme.

\section{Phytase from Asperguillus fumigates}

In the investigation realized by Rodriguez et al. (Rodriguez et al., 2000) the analysis was focused on the differences presented in the recombinant protein obtained from Pichia pastoris vs. those obtained in other expression systems. The gene r-Afp expressed in P. pastoris in pPICZ $\alpha \mathrm{A}$ vector, obtained yield of $729 \mathrm{mg}$ of purified protein per liter of culture, with a specific activity after purification of $43 \mathrm{U} / \mathrm{mg}$ at $\mathrm{pH} 5.5$ of protein has a comparatively higher specific phytase activity than those reported values of the enzyme produced by $A$. niger, $H$. polymorpha, and $S$. cerevisiae which varied between 23.4 to $28.1 \mathrm{U} / \mathrm{mg}$ protein. The remarkable resistance of the $A$. fumigates phytase to heat inactivation is most appealing characteristic (Pasamontes et al., 1997). In assay for temperature stability was conserved at $65{ }^{\circ} \mathrm{C}$ around of $57 \%$ and for $90^{\circ} \mathrm{C}$ around of
$40 \%$. Another interesting observation in this study is the relatively high resistance of r-Afp to pepsin. Given the ratios of pepsin/phytase (w/w) from 0.001 to 0.1 , r-Afp remained essentially intact after $2 \mathrm{~h}$ of incubation at $37^{\circ} \mathrm{C}$. On the other hand, the enzyme was degradable by trypsin depending on the ratios. While r-Afp was partially digested from the ratio of 0.001 to 0.02 , the enzyme was fully degraded at the ratio of 0.1 ; suggests this results that r-Afp has different susceptibilities to proteolysis of pepsin and trypsin.

\section{Phytase from Escherichia Coli}

In this study executed by Chen et al. (2004) was evaluated and compared the production of recombinant protein in flask scale and high cell-density fermentation, the app $A$ gene cloned in pPICZ $\alpha \mathrm{A}$ vector of $P$. pastoris registered phytase activity level was enhanced from 118 to $204 \mathrm{U} / \mathrm{mL}$ at the flask scale and 1880-4946 U/mL for high cell-density fermentation, this high yield would thus suggest that phytase production by $P$. pastoris was both economical and feasible. The most important result in this study is focusing in modified media for enhances the induction of recombinant protein; the phytase production was increased when a modified mBMMHY medium was used. The mBMMHY medium was modified from BMMY medium by replacing peptone and YNB with histidine and the YE concentration was reduced from 1 to $0.1 \%$. The phytase activity in mBMMHY was $204 \mathrm{U} / \mathrm{mL}$ after an induction period of $96 \mathrm{~h}$, virtually twice the level that it achieved when induction was conducted in BMMY or FBSH 118 and $123 \mathrm{U} / \mathrm{mL}$ respectively after $96 \mathrm{~h}$ induction. The protein concentration of cells induced in mBMMHY medium reached $6.4 \mathrm{~g} / \mathrm{L}$ of culture supernatant and the phytase activity was noted to be $4946 \mathrm{U} / \mathrm{mL}$ after an induction period of $192 \mathrm{~h}$.

\section{Gelatin industry}

Gelatin is in essence, denatured collagen and is prepared by hot acid or alkaline extraction of animal tissues such as bones and hides; is a well-known biopolymer and has a long history of use, mainly as a gelling agent in food. Certain characteristics limited their applications, the extraction procedure results in chemically modified gelatin peptides covering a wide range of molecular weights (Asghar and Henrickson, 1982) and traditional gelatin has a high gelling temperature due to its high content of helix-stabilizing hydroxyprolines. This can be undesirable for low temperature applications (Saddler and Horsey, 1987).

Production of non-gelling (i.e. non-hydroxylated) gelatin-like proteins in Escherichia coli has been reported. It involves the expression of synthetic genes constructed from repeating Gly-Xaa-Yaa encoding units (Gardner et al., 1992). Many problems arise concerning the instability of these highly repetitive genes (Capello, 1990). Probably, native gelatin sequences derived from collagen genes are more stable than synthetic gelatin-like sequences, because 
there is greater variation in amino acid usage and less repetitiveness (Fahnestock and Bedzyk, 1997).

\section{Non-gellins gellatin}

In report, generated by Werten et al. (1999) the production of high extracellular non-gelling gelatin in pPIC9 and a multicopy pPIC9K expression vectors of Pichia pastoris was described. A $0.7 \mathrm{~kb}$ rat denominated COL $3 \mathrm{Al}$ cDNA fragment, encoding a $21 \mathrm{kDa}$ gelatin and a $1.0 \mathrm{~kb}$ mouse denominated COL1A1 cDNA fragment encoding a $28 \mathrm{kDa}$ gelatin (Colla1-1) and a $1.8 \mathrm{~kb}$ mouse denominated COL1A1 cDNA fragment encoding a $53 \mathrm{kDa}$ gelatin (Col1a1-2) were cloned. Different strategies were used to reduce the proteolytic degradation of this extremely vulnerable unfolded protein, the best results was obtained from a transformant bearing approximately 15 copies of the pCOL3A1 vector produced up to $14.8 \mathrm{~g}$ gelatin/liter extracellular medium and the problems of proteolytic degradation could be minimized despite the unfolded structure of gelatin trough modifications of $\mathrm{pH}$ fermentation and supplement the fermentation medium with casamino acids; proteolytic cleavage at specific mono-arginylic sites, by a putative Kex2-like protease, could be

successfully abolished by site-directed mutagenesis of these sites.

\section{Wastewater Treatment and Bleaching}

Laccases are blue copper-containing phenol oxidases that are widely distributed in plants and certain fungi (Alcalde, 2007). Have been ascribed diverse biological functions in different organism; the potential applications include (i) delignification and biobleaching of pulp (Bourbonnais et al., 1997) (ii) treatment of wastewater from industrial plants (Bergbauer et al., 1991) (iii) enzymatic modification of fibers and dye-bleaching in the textile and dye industries (Abadulla et al., 2000). A possible advantage with $P$. pastoris compared to many filamentous fungi is that it does not produce cellulolytic enzymes and laccase produced in this host could, therefore, potentially be applied directly in the pulp and paper industry without any purification.

\section{Laccase from Trametes versicolor}

The work realized by Hong et al. (Hong et al., 2002) utilized the gene laccase $l c c l$ and was cloned into $P$. pastoris in pHIL-D2 expression vector. Was employed the BMM medium, and the highest laccase activity registred was $3.3 \mathrm{U} / \mathrm{mL}$, which was observed after 3 days of induction; after that it declined to $1.6 \mathrm{U} / \mathrm{mL}$. The decrease in laccase activity during the late period in shake-flask cultivation might be due to the low $\mathrm{pH}$. The temperature is an important parameter for optimization of laccase expression in yeast systems (Cassland and Jonsson, 1999), the results confirmed that cultivation at low temperature in shakeflask improved laccase activity $3.3 \mathrm{U} / \mathrm{mL}$ at $30^{\circ} \mathrm{C}$ and
$11.5 \mathrm{U} / \mathrm{mL}$ at $20^{\circ} \mathrm{C}$. When fermentor cultivations was used the $\mathrm{pH}$ was kept at 5.0 and in the protease assay higher proteolytic activity was found at $\mathrm{pH} 5.0$ than at $\mathrm{pH} 8.5$, a previous investigation indicated that proteolytic activity played an important role in laccase expression by $P$. pastoris because the protease deficient SMD 1168 strain performed better than GS115. In the study a positive correlation was established between the amount of methanol consumed and the quantity of protein produced was observed, however a fivefold higher volumetric laccase activity was obtained when the methanol concentration was kept at $0.5 \%$ instead of $1.0 \%$.

\section{Laccase from Pleurotus sajor-caju}

Research realized by Soden et al. (2002) report the cloning of the full-length gene for one of these isozyme genes, namely Psc lac4, and on its subsequent expression in the heterologous host $P$. pastoris. The GS115 strain was utilized transformed with pPIC3.5-lac4, the level of Psc Lac 4 expression reported here was $4 \pm 85 \mathrm{mg} / \mathrm{L}$ the purified protein had an activity of $1050 \mathrm{U} / \mathrm{mL}$, with a specific activity of 2100 units mg $^{-1}$. Psc Lac 4 was stable for at least $5 \mathrm{~h}$ between $\mathrm{pH} 6$ and $\mathrm{pH} 8$. Over the same period of time, the activity decreased to approximately $80 \%, 70 \%$ and $64 \%$ of the original value when the enzyme was incubated at $\mathrm{pH} 5$, $\mathrm{pH} 3$ and $\mathrm{pH} 9$, respectively. At $25^{\circ} \mathrm{C}$, the $\mathrm{pH}$ stability of Psc Lac 4 was reduced. The optimal temperature for Psc Lac4 activity was $35^{\circ} \mathrm{C}$ with ABTS as substrate. Psc Lac4 was relatively stable after $1 \mathrm{~h}$ at $35^{\circ} \mathrm{C}$; however, over the same period of time residual activity decreased to approximately $35 \%$ and $25 \%$ of the original value when incubated at $35^{\circ} \mathrm{C}$ and $45^{\circ} \mathrm{C}$ respectively, while no detectable activity was observed after $1 \mathrm{~h}$ at $65^{\circ} \mathrm{C}$.

\section{Laccase from Pycnoporus cinnabarinus I-937}

Studies realized by Otterbein et al. (2000) was dedicated to isolation and characterization of a cDNA corresponding to the gene lacl isolated from fungus $P$. cinnabarinus I-937 and its expression in the methylotrophic yeast $P$. pastoris; two distinct expression plasmids were used. Plasmid pPICZB/Lac1 and pPICZaB/Lac1 differs from the first in that it contains the native $S$. cerevisiae $\alpha$-factor secretion signal upstream of the sequence of mature laccase. Expression was evaluated in baffled flasks and for $\mathrm{pPICZ} \alpha \mathrm{B} / \mathrm{Lac} 1$ construction, the laccase activity gradually reached 20 units, and the cell culture density reached a D600 of 21 after 10 days of incubation for other hand for the pPICZ/Lac1 expression vector, laccase activity reached a maximum of 12 units and the cellular density reached a D600 value of 17 after 8 days, the expression level was satisfactory $8 \mathrm{mg} / \mathrm{L}$ with the two expression vectors used, but the eventual proteolytic degradation events in the culture medium could not be regulated, the regulation of $\mathrm{pH}$ in the media utilized was important factor for the production of 
laccase enzyme, obtaining in acidic $\mathrm{pH}$ an detrimental effect in the production.

\section{Antifreeze}

Antifreeze proteins (AFP) have been isolated from a number of organisms including fish, insects, plants and bacteria (Davis and Hew, 1990). Their properties include depressing freezing temperature without affecting the melting temperature (so-called thermal hysteresis), modifying ice crystal morphology, inhibiting ice crystal growth (recrystallization), enhancing cellular integrity, and reducing microbial growth (Chapsky and Rubinsky, 1997; Harding et al., 1999).

The use of AFPs is focused on industry foodstuffs that involved frozen storage. However, according to their properties, AFPs are likely to be good preservatives, not only for frozen food but also for chilled food (Griffith and Ewart, 1995).

In the work realized by Loewen et al. (1997) describing the shake-flask expression of the cystine-rich SRAFP in Pichia obtaining secreted recombinant protein up to $5 \mathrm{mg} / \mathrm{L}$ and demonstrate that the recombinant protein has identical activity to SRAFP isolated from sea raven serum. In order to increase yields further, four different strategies were tested in 10 liter fermentation vessels, the mixedfeeding/Mut strategy proved to be the most efficient with SRAFP yields reaching $30 \mathrm{mg} / \mathrm{L}$.

\section{Lytic Enzymes}

Enzymes such as cellulases, xylanases, proteases, lipases, amylases, phosphatases and pectinases are widely used in the pulp and paper, textiles, detergent, food and beverage and pharmaceutical industries (Cheng et al., 1999).

The main industrial application of pectinases is the extraction and clarification of fruit and vegetable juices. Most of the microbial pectinases produced by the industry are dedicated to this purpose. Pectins are responsible for the turbidity and consistency of the juice causing an increase in their viscosity, which hinders its clarification, filtration and concentration (Alkorta et al., 1998).

Polygalacturonases are the pectic enzymes which are most commonly used in the case of orange juice, where natural pectin esterases are present, pectin is only partially methylated. In the process of orange juice extraction, pectinases can be added at the end of the pulp wash extraction to reduce viscosity or, preferably, at the end of the first finisher. This leads to higher yield in juice, a better extraction of soluble solids and to a lower viscosity. The action of these enzymes just reduces the viscosity without attacking the insoluble pectin that maintains the stability of the cloud (Kashyap et al., 2001). The endopolygalacturonase is the most substantial member of pectolytic enzymes that are uti- lized to degrade various pectic substances (Whitaker, 1990).

Cellulases and xylanases are active fibrolytic enzymes and have sparked interest for a number of biotechnological applications. These include development of probiotic and as feed additives for silages and total mixed rations, for saccharification of lignocellulosic residues and for production of polysaccharide-hydrolysing enzymes ( $\mathrm{Li}$ et al., 1996).

Xylan is the second most abundant biopolymer after cellulose and the major hemicellulosic polysaccharide found in plant cell walls. Xylanolytic enzymes are mainly produced by saprophytic fungi and bacteria and hydrolyze the xylan component of plant cell walls (Coughlan and Hazlewood, 1993).

\section{Endopolygalacturonase from Botrytis cinerea}

In investigation realized by Kars et al. (2005) the coding sequences of the genes Bcpg1, Bcpg2, Bcpg3, Bcpg4 and Bcpg6 were cloned in the expression vector pPIC3.5 of P. pastoris. Production levels of BcPGs were reproducible for individual enzymes but varied significantly between the different enzymes, ranging from $5 \mathrm{mg} / \mathrm{L}$ for BcPG1 to $1000 \mathrm{mg} / \mathrm{L}$ for BcPG3. The overall yield of pure protein of the different BcPGs was highly variable ranged from 0.5 to $500 \mathrm{mg}$ per fermentation. The optimal enzyme activity using polygalacturonic acid (PGA) as substrate was observed at $\mathrm{pH} 4.2$ for $\mathrm{BcPG} 1, \mathrm{pH} 4.9$ for $\mathrm{BcPG} 4$, and $\mathrm{pH} 4.5$ for BcPG2 and BcPG6. Purified BcPG3 displayed a broader $\mathrm{pH}$ optimum ranging from $\mathrm{pH} 3.2$ to 4.5.

\section{Endo- $\beta-1,4-x y l a n a s e$ from Aspergillus niger}

In the working realized by Berrin et al. (2000); the cDNA-encoding XylA was used to transform $P$. pastoris and the cells with construction obtain a secretion yields up to $50-100 \mathrm{mg} /$ liter were obtained in selective medium. The specific activities of recombinant xylanase of $A$. niger were $350 \pm 25 \mathrm{U} \mathrm{mg} / \mathrm{L}$ for the one expressed in Pichia and 270 $\pm 16 \mathrm{U} \mathrm{mg} / \mathrm{L}$ for the native xylanase over expressed. The optimum reaction temperature of both xylanases was found at $50{ }^{\circ} \mathrm{C}$ and over $70 \%$ of maximal activity between 40 and $60{ }^{\circ} \mathrm{C}$. Around $90 \%$ activity remained after $3 \mathrm{~h}$ incubation at $50^{\circ} \mathrm{C}$ but between 3 and $4 \mathrm{~h}$ of incubation at this temperature, xylanase activity dropped dramatically and decreased by more than $50 \%$.

\section{Conclusion}

All revised investigation in this review demonstrating the major production of product when the Pichia pastoris expression system was utilized and when this is compared with other expression system like E. coli, S. cereviciae or $H$. polimorpha. Recombinant protein obtained in $P$. pastoris system exhibit one aspect that has improved is the specific activity of the enzyme produced, detecting in- 
creased enzyme activity when this was assessed. Being this a highly relevant aspect because when a recombinant protein is destined to industry use, the yield of the product is an important factor for profitability of the process.

\section{Acknowledgments}

The authors are sincerely thankful for support provided by CONICYT doctoral fellowship to D.W, FAPESP 12/50210-9 (Fundação de Amparo à Pesquisa do Estado de São Paulo, Brasil) and International Cooperation Program of Universidad de La Frontera DI12-4001.

\section{References}

Abadulla E, Tzanov T, Costa S, Robra KH, Cavaco-Paulo A, Gubitz GM (2000) Decolorization and detoxification of textile dyes with a laccase from Trametes hirsuta. Appl Environ Microbiol 66:3357-3362.

Alcalde M (2007) Laccases: Biological functions, molecular structure and industrial applications. In Polaina, J. and MacCabe, A. (Eds), Industrial Enzymes, Springer Netherlands, pp 461-476.

Alkorta I, Garbisu C, Llama MJ, Serra JL (1998) Industrial applications of pectic enzymes: a review. Process Biochem 33:21-28.

Asghar A, Henrickson RL (1982) Chemical, Biochemical, Functional, and Nutritional Characteristics of Collagen in Food Systems In C.O. Chichester, E.M. M.; Stewart, G. F. (Eds), Advances in Food Research, Academic Press, pp.231-372.

Bergbauer M, Eggert C, Kraepelin G (1991) Degradation of chlorinated lignin compounds in a bleach plant effluent by the whiterot fungus Trametes versicolor. Appl Microbiol Biotechnol 35:105-109.

Berrin J-G, Williamson G, Puigserver A, Chaix J-C, RussellMcLauchlan W, Juge N (2000) High-Level Production of Recombinant Fungal Endo-b-1,4-xylanase in the Methylotrophic Yeast Pichia pastoris. Protein Expr Purif 19:179187.

Bourbonnais R, Paice MG, Freiermuth B, Bodie E, Borneman S (1997) Reactivities of various mediators and laccases with kraft pulp and lignin model compounds. Appl Environ Microbiol 63:4627-4632.

Buckholz R, Gleeson M (1991) Yeast systems for the commercial production of heterologous protein. Nat Biotech 9:10671072.

Cassland P, Jönsson LJ (1999) Characterization of a gene encoding Trametes versicolor laccase A and improved heterologous expression in Saccharomyces cerevisiae by decreased cultivation temperature. Appl Microbiol Biotechnol 52:393-400.

Capello J (1990) The biological production of protein polymers and their use. Trends Biotechnol 8:309-311.

Chapsky L, Rubinsky B (1997) Kinetics of antifreeze proteininduced ice growth inhibition. FEBS Lett. 412:241-244.

Chen CC, W PH, Huang CT, Cheng KJ (2004) A Pichia pastoris fermentation strategy for enhancing the heterologous expression of an Escherichia coli phytase. Enzyme Microb Tech 35:315-320.
Cheng KJ, Lee SS, Bae HD, Ha K (1999) Industrial applications of rumen microbes - review. Asian-Aust. J Anim. Sci 12:84-92.

Cheryan M (1980) Phytic acid interactions in food systems. Crit. Rev. Food Sci. Nutr. 13:297-335.

Cregg JM, Vedvick TS, Raschke WC (1993) Recent Advances in the Expression of Foreign Genes in Pichia pastoris. Nat BioTech 11:905-910.

Coughlan MP, Hazlewood GP (1993) B-1,4-D-xylan-degrading enzyme systems: biochemistry, molecular biology and applications. Biotechnol Appl Biochem 17:259-289.

Daly R, Hearn Milton TW (2004) Expression of heterologous proteins in Pichia pastoris: a useful experimental tool in protein engineering and production. J. Mol. Recognit. 18:119-138.

Davies PL, Hew CL (1990) Biochemistry of fish antifreeze proteins. The FASEB Journal 4:2460-2468.

Fahnestock SR, Bedzyk LA (1997) Production of synthetic spider dragline silk protein in Pichia pastoris. Appl Microbiol Biotechnol 47:33-39.

Gardner K, Lock RL, O'Brien JP and Salemme FR (1992) Collagen-like polypeptides. Patent Application PCT/US92/09655.

Griffith M, Ewart KV (1995) Antifreeze proteins and their potential use in frozen foods. Biotechnol Adv 13:375-402.

Harding MM, Ward LG, Haymet ADJ (1999) Type I antifreeze proteins: structure activity studies and mechanisms of ice growth inhibition. European J Biochem 264:653-665.

Hong F, Meinander NQ, Jönsson LJ (2002) Fermentation strategies for improved heterologous expression of laccase in Pichia pastoris. Biotechnol Bioeng 79:438-449.

Kars I, Krooshof G, Wagemakers L, Jooten R, Benen J, van Kan J (2005) Necrotizing activity of five Botrytis cinerea endopolygalacturonases produced in Pichia pastoris. Plant J 43:213-225.

Kashyap DR, Vohra PK, Chopra S, Tewari R (2001) Applications of pectinases in the commercial sector: a review. Bioresour Technol 77:215-227.

Li P, Anumanthan A, Gao XG, Ilangovan K, Suzara VV, Düzgünes N, Renugopalakrishnan V (2007) Expression of Recombinant Proteins in Pichia Pastoris. Appl Biochem Biotechnol 142:105-124.

Li X-L, Chen H, Ljungdahl GL (1996) Cloning sequencing and over-expression of a xylanase cDNA in Escherichia coli of the polycentric anaerobic fungus Orpinomyces $s p$. Strain PC-2. Proc $96^{\text {th }}$ Ann Meet Amer Soc Microbiol New Orleans, L.A. p.361.

Loewen MC, Liu X, Davies PL, Daugulis AJ (1997) Biosynthetic production of type II fish antifreezen protein fermentation by Pichia pastoris. Appl Microbiol Biotechnol 48:480-486.

Otterbein L, Record E, Longhi S, Asther M, Moukha S (2000) Molecular cloning of the cDNA encoding laccase from Pycnoporus cinnabarinus I-937 and expression in Pichia pastoris. Eur J Biochem 267:1619-1625.

Pasamontes L, Haiker M, Henriquez-Huecas M, Mitchell DB, van Loon AP (1997) Cloning of the phytases from Emericella nidulans and the thermophilic fungus Talaromyces thermophilus. Biochim Biophys Acta 1353:217-23.

Rodriguez E, Mullaney EJ, Lei X-G (2000) Expression of the Aspergillus fumigatus Phytase Gene in Pichia pastoris and Characterization of the Recombinant Enzyme. Biochem Biophys Res Commun 268:373-378. 
Romanos MA, Scorer CA, Clare JJ (1992) Foreign Gene Expression in Yeast: A Review. Yeast 8:423-488.

Saddler JM, Horsey PJ (1987) The new generation gelatins. A review of their history, manufacture and properties. Anesthesia 42:998-1004.

Soden DM, O'Callaghan J, Dobson DW (2002) Molecular cloning of a laccase isozyme gene from Pleurotus sajur-caju and expression in the heterologous Pichia pastoris host. Microbiology 148:4003-4014.

Torre M, Rodríguez AR, Saura-Calixto F (1991) Effects of dietary fiber and phytic acid on mineral availability. Crit Rev Food Sci Nutr 30:1-22.
Werten M, Van Den Bosch T, Wind R, Mooibroek H, De Wolf F (1999) High-yield Secretion of Recombinant Gelatins by Pichia pastoris. Yeast 15:1087-1096.

Whitaker JR (1990) Microbial pectinolytic enzymes. Microbial enzymes and biotechnology (2nd edition), W.M. Fogarty \& C.T. Kelly, (Eds.), pp.133-176, Elsevier Science Ltd., London, England.

All the content of the journal, except where otherwise noted, is licensed under a Creative Commons License CC BY-NC. 